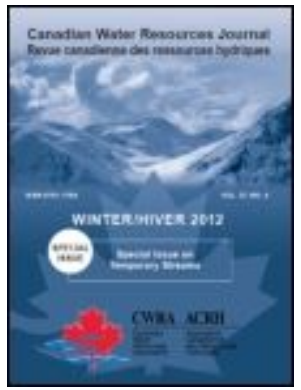

\title{
Seasonal contributions of water and pollutants to Lake St. Charles, a drinking water reservoir
}

\begin{tabular}{|r|l|}
\hline Journal: & Canadian Water Resources Journal \\
\hline Manuscript ID & TCWR-2019-0028.R1 \\
\hline Manuscript Type: & Original Paper \\
\hline Author: & n/a \\
\hline Complete List of Authors: & $\begin{array}{l}\text { Narancic, Biljana; INRS, Eau-Terre Environnement } \\
\text { Laurion, Isabelle; INRS, Eau-Terre Environnement } \\
\text { Wolfe, Brent B.; Wilfrid Laurier University, Geography and Environmental } \\
\text { Studies } \\
\text { Behmel, Sonja; Association pour la protection de l'environnement du lac } \\
\text { Saint-Charles et des Marais du Nord, Limnology } \\
\text { Rousseau, Alain; INRS, Eau-Terre Environnement }\end{array}$ \\
\hline Keywords: & $\begin{array}{l}\text { stables isotopes; nutrients; fecal coliforms; septic installations; } \\
\text { wastewater treatment plants; }\end{array}$ \\
\hline
\end{tabular}

\section{SCHOLARONE Manuscripts}


4 Biljana Narancic ${ }^{1}$, Isabelle Laurion ${ }^{1}$, Brent B. Wolfe ${ }^{2}$, Sonja Behmel ${ }^{3}$ and Alain N.

$5 \quad$ Rousseau ${ }^{1}$

$7 \quad{ }^{1}$ Centre Eau Terre Environnement, Institut national de la recherche scientifique, Québec,

8 QC G1K 9A9, Canada

$9 \quad{ }^{2}$ Department of Geography and Environmental Studies, Wilfrid Laurier University,

10 Waterloo, ON N2L 3C5, Canada

$11{ }^{3}$ Association pour la protection de l'environnement du lac Saint-Charles et des Marais du

12 Nord, Québec, QC G3G 1H4, Canada

14 Corresponding author: Biljana Narancic (now at Laboratoire de paléoécologie aquatique,

15 Centre d'études nordiques, Département de géographie, Université Laval, QC G1V 0A6,

16 Canada)

17 E-mail: biljana.narancic.1@ulaval.ca

18 ORCID ID: orcid.org/0000-0002-4986-6927

19

20

21 


\section{Abstract}

24 Surface waters are widely used as sources of drinking water in Canada. The identification

25 of the main sources of pollutants to surface waters, often associated with increasing

26 urbanization, is needed to improve management strategies. We used stable water isotopes

$27\left(\delta^{18} \mathrm{O}\right.$ and $\left.\delta \mathrm{D}\right)$, and nutrient and fecal coliform mass fluxes to estimate the seasonal

28 contributions of water and pollutants of different inflows to Lake St. Charles (LSC). Our

29 results indicate that out of six identified LSC water sources, groundwater (GW), Hurons

30 River (HR) and small stream tributaries (SSTs) represent the major contributors (in terms

31 of water volume). The three other water sources, including two wastewater treatment

32 plants (WWTPs), Delage Lake (DL) and precipitation (rain and snow), represent smaller

33 seasonal contributions. During the high-flow seasons (spring and fall), LSC receives

34 water mainly from SSTs and HR, while during the low-flow season (summer), the lake

35 relies mainly on GW inflows. Estimates of point source (WWTPs) versus non-point

36 source (primarily septic installations) concentrations of nutrients and fecal coliforms

37 show that the latter represents a seasonally variable and greater source of pollutants (5\%

38 WWTPs vs. $95 \%$ septic installations). HR and SSTs, draining densely occupied areas of

39 single housing units with individual septic installations, are categorized as non-point

40 sources, and as such are considered major nutrient and fecal coliform contributors. The

41 higher precipitation in spring and fall caused increased fluxes of nutrients and fecal

42 coliforms through higher stream discharge. Due to the seasonally variable and difficult to

43 predict discharge dynamics of SSTs and HR, these two sources represent a potentially

44 larger threat to LSC water quality. We advocate that improved management requires

45 reducing the number of individual septic installations in the LSC watershed. 


\section{Résumé}

48 Les eaux de surface sont largement utilisées comme sources d'eau potable au Canada.

49 L'identification des principales sources de polluants dans les eaux de surface, souvent

50 associées à une urbanisation croissante, est nécessaire pour élaborer des stratégies de

51 gestion améliorée. Nous avons utilisé des isotopes stables dans l'eau $\left(\delta^{18} \mathrm{O}\right.$ et $\left.\delta \mathrm{D}\right)$ et des

52 charges en nutriments et coliformes fécaux pour estimer les contributions saisonnières de

53 différents affluents vers le lac Saint-Charles (LSC). Nos résultats indiquent que parmi les

54 six sources d'eau identifiées, les eaux souterraines (GW), la rivière des Hurons (HR) et

55 les petits tributaires (SSTs) représentent les principaux contributeurs (en termes de

56 volume d'eau). Les trois autres sources d'eau, dont deux stations d'épuration d'eaux usées

57 (WWTPs), Lac Delage (DL) et les précipitations (pluie et neige), représentent une

58 contribution saisonnière moins importante. Pendant les saisons de fort débit (printemps et

59 automne), LSC reçoit de l'eau principalement des SSTs et HR, tandis que pendant la

60 saison de faible débit (été), le lac dépend principalement de GW pour maintenir son

61 niveau d'eau. Les estimations des sources ponctuelles (WWTPs) par rapport aux sources

62 non ponctuelles (principalement des installations septiques) de nutriments et coliformes

63 fécaux ont démontré que cette dernière source représente une contribution saisonnière

64 variable, mais plus importante de polluants (5\% des WWTPs contre $95 \%$ des installations

65 septiques). HR et SSTs qui drainent les zones densément occupées par des maisons avec

66 des installations septiques privées, sont classées comme des sources non ponctuelles et, à

67 ce titre, sont considérées comme des contributeurs majeurs en nutriments et coliformes

68 fécaux. Les précipitations plus abondantes au printemps et à l'automne ont entraîné une

69 augmentation des flux de nutriments et coliformes fécaux en raison du débit plus élevé.

70 La dynamique de débits saisonniers difficile à prévoir des SSTs et HR, représente une 
71 menace potentiellement plus grande pour la qualité de l'eau du LSC que d'autres sources.

72 Nous préconisons que l'amélioration de la gestion nécessite de réduire le nombre

73 d'installations septiques privées dans le bassin versant du LSC.

74

75 Keywords: Quebec; stables isotopes; nutrients; fecal coliforms; septic installations;

76 wastewater treatment plants;

77 


\section{Introduction}

79 In Canada, two-thirds of the population depend on surface waters from lakes, rivers and

80 reservoirs for their drinking water supply (Statistics Canada 2011). In southern Quebec,

81 surface waters provide more than $75 \%$ of the drinking water (MDDEP 2008).

82 Increasingly, people are moving out of city centers, because of lower housing prices, and

83 developers are quickly converting forested areas and floodplains into building lots to

84 respond to this growing demand, and as a consequence replacing land cover serving as

85 natural filters (Ritchot et al. 1994)). The accelerated urbanization, often not connected to

86 sewer systems, particularly in the urban-rural fringe areas, is viewed as a major threat to

87 long-term sustainability in water quality and quantity and represents a major challenge

88 for water managers.

89 Lake St. Charles (LSC) is the main drinking water reservoir of Quebec City

90 providing drinking water to 300,000 inhabitants and is located in the urban-rural fringe

91 area. There is increasing evidence that the lake water quality is undergoing accelerated

92 degradation associated with increased urbanization (Tremblay et al. 2002; Tremblay and

93 Pienitz 2015; APEL 2014b and 2019). Based on APEL reports (Association pour la

94 protection de l'environnement du lac Saint-Charles et des Marais du Nord; 2012, 2014a,

95 2014b), a non-profit lake steward organization, urban development is increasing faster

96 than the infrastructure capacity (e.g., the capacity of the two wastewater treatment plants

97 upstream from Lake St. Charles in addition to the increasing number of housing on septic

98 installations), and regulations are needed to control diffuse (non-point) and point sources

99 of pollution from domestic waste water sources. Residential development and increased

100 discharge of domestic wastewaters into the lake have substantially increased during the 
101 past 50 years (APEL 2019). These land cover changes have accelerated the lake

102 eutrophication process and ensuing degradation rate, which is already perceptible by

103 occurrences of cyanobacterial blooms occurrence, aquatic plant proliferation and

104 increased water salinity (Légaré 1997, 1998; APEL 2012, 2014a). Indeed, the lake was

105 classified as mesotrophic when considering both nutrient and algal biomass (APEL

106 2014b). Within the lake watershed, there are two wastewater treatment plants (WWTPs)

107 serving close to 5000 people. WWTPs are permanent point sources of nutrients and

108 pollutants. In addition, approximately 3 000, single housing units with on-site septic

109 installations composed of a sedimentation tank and purification field, viewed as non-

110 point sources of pollution, are also located within the LSC watershed.

111 Several studies have observed that septic installation failure contributes to water

112 quality degradation, but even a properly working septic installation, which has a working

113 life expectancy between 10 to 20 years, does not handle all pollutants effectively and is

114 likely insufficient to prevent pollution of downstream waterbodies and groundwaters

115 (Aravena et al. 1992; Wilhelm et al. 1996; Ptacek 1998; Robertson et al. 1998; Wernick

116 et al. 1998; Arnade 1999; Moore et al. 2003). To our knowledge, there are no studies that

117 have focused on the efficiency of septic installations and contributing pollution to LSC

118 based on geochemical proxies, and the same can be said for the two WWTP effluents

119 located within its drainage area. The study of Wernick et al. (1998) advocates that

120 individual septic installations are one of the main non-point sources of nitrogen pollution

121 in stream waters. In their comparison between lakes with houses connected to a central

122 sewer system and those surrounded by houses with individual septic installations, Moore 
123 et al. (2003) concluded that the latter had higher levels of phosphorous and chlorophyll-a 124 concentrations.

125 The two municipalities located within the LSC watershed, are considering the 126 possibility of connecting individual septic installations to their local sewer systems 127 (modernised WWTPs) and/or diverting their domestic wastewaters to WWPT located in 128 Quebec City, that is beyond the lake watershed. Therefore, there is a need to identify the

129 dominant pollutant sources in order to prioritize investments. To provide municipalities

130 with this knowledge, we assessed and compared intra- and inter-annual contributions of

131 point (WWTPs) and non-point sources (septic installations drained by small stream

132 tributaries) of waters, nutrients and fecal coliforms located within the LSC watreshed. We

133 used water stable isotopes $\left(\delta^{18} \mathrm{O}\right.$ and $\left.\delta \mathrm{D}\right)$ to partition water sources to LSC, and

134 limnological tracers (mass fluxes, that is loadings, of phosphorus, nitrogen and fecal

135 coliform) to assess the transport of pollutants to LSC over a two-year period. Stable

136 isotope analysis is often used to determine the relative contribution of different water

137 sources, but also about the evaporation effects, precipitation patterns and groundwater

138 recharge (Clark and Fritz 1997; Turner et al. 2010; Tondu et al. 2013; Narancic et al.

139 2017). Moreover, water stable isotopes are considered water management tools (Tondu et

140 al. 2013). Here we used a linear mixing model for partitioning six lake water sources

141 using $\delta^{18} \mathrm{O}$ and $\delta \mathrm{D}$. The isotopic similarity of LSC waters to individual water sources is

142 used to estimate their relative contribution to the lake water balance.

143 The estimation of nutrient and fecal coliform mass fluxes to the lake is paramount

144 in assessing the sustainability of LSC water quality. The characterization of the mass

145 fluxes through our applied hydro-limnological approach will inform governance 
146 strategies to improve or avoid further degradation of lake water quality. The results can

147 also serve to improve the hydrological modelling through a more complete description of

148 seasonal changes in limnological conditions, and to make projections linked to climate

149 change, which is especially critical for this municipal source of drinking water.

151 Materials and Methods

152 Study site

153 LSC $\left(46^{\circ} 55^{\prime} \mathrm{N}, 71^{\circ} 22^{\prime} \mathrm{W}\right)$, located $20 \mathrm{~km}$ northwest of Quebec City (Canada), is a

154 medium-size lake reservoir $\left(3.6 \mathrm{~km}^{2}\right)$ with a deeper northern (up the lake) basin

155 (maximum depth $=17.5 \mathrm{~m}$ ) and shallower southern basin (towards the lake outlet;

156 maximum depth $=4.5 \mathrm{~m}$; Figure 1). The drainage area of the watershed is $198 \mathrm{~km}^{2}$,

157 transgressing the administrative boundaries of five neighbouring municipalities:

158 Stoneham-and-Tewkesbury, City of Lac Delage, Quebec City, Saint-Gabriel-de-

159 Valcartier and Lac Beauport (Figure 1). Based on previous studies, the main sources of

160 water to LSC come from the Hurons River, Delage Lake, and 34 small streams,

161 respectively draining $82 \%, 4 \%$ and $11 \%$ of the watershed. Diffuse runoff from lake

162 hillslopes were estimated to drain the remaining $3 \%$ of the watershed (APEL 2014b).

163 LSC discharges into the St. Charles River via a dam that separates the lake and the river.

164 The dam was built in 1934 to create the drinking water reservoir for Quebec City (APEL

165 2014a; APEL 2019), and is now a run-of-the-river type dam since 2012. The short water

166 residence time, ca. 23 days for the northern basin and ca. 8 days for the southern basin,

167 characterises LSC as a fluvial lake system (Légaré 1998; Tremblay et al. 2002). [Figure 1 168 near here] 
169 LSC is located on the Canadian Shield in an ancient glacial valley surrounded by steep

170 hills with altitudes varying between $150-450 \mathrm{~m}$ (the highest peak is at $750 \mathrm{~m}$; Tremblay

171 et al. 2002). Surface deposits are thin with outcrops (APEL 1981). Upstream surface

172 water has naturally low ionic charge, and thus, low conductivity and $\mathrm{pH}(78.6 \mu \mathrm{S} / \mathrm{cm}$ and

$1736.7 \mathrm{pH})$. Approximately, $70 \%$ of the lake watershed is covered by dense forests,

174 dominated by deciduous and mixed wood stands. Significant macrophyte growth occurs

175 in shallow areas along the lake shores. Since 2012, macrophyte growth has been

176 extensive and tends to cover $55 \%$ of the southern basin area and $36 \%$ of the northern

177 basin area (APEL 2014b).

178 Today, approximately 13000 people live in the lake watershed, with more than 4

179000 housing units located close to the shores (i.e. at less than $500 \mathrm{~m}$; APEL 2014b). More

180 than half of these housing units have on-site individual septic installations. Given the

1811960 population growth in the lake watershed, some of these septic installations are more

182 than 50 years old (APEL 2019 and references therein). In 1990, two WWTPs were built

183 for the towns of Stoneham-and-Tewkesbury and City of Lac Delage. Both WWTPs have

184 aerated lagoons. Since 2017, the Stoneham-and-Tewkesbury WWTP uses tertiary

185 treatment of sewage discharge and treated waters are directly flushed out through an

186 underground pipe system into Hurons River, ca. 4 km upstream of LSC. City of Lac

187 Delage WWTP provides alum-based coagulation to treat the wastewaters, and treated

188 waters are discharged into marshes (Northern Marshes) upstream of LSC (Figure 1).

189 According to the 1981-2010 climate normal from the closest Environment and

190 Climate Change Canada meteorological station (Jean-Lesage airport, Station ID

191 7016294), the average annual temperature and precipitation are $4.2^{\circ} \mathrm{C}$ and $1190 \mathrm{~mm}$, 
192 respectively (Environment Canada 2017). Most of the precipitation (ca. 75\%) falls as

193 rain. The lake is covered by ice from December to April. Annual precipitation for 2016 (1

$194337 \mathrm{~mm}$ ) and $2017(1231 \mathrm{~mm})$ were slightly above the 1981-2010 climate normal. Both

195 years had exceptionally wet conditions during the spring and fall $(710 \mathrm{~mm}=2016 ; 753$

$196 \mathrm{~mm}=2017$; compared to $595 \mathrm{~mm}=30$-year climate average) and drier than normal

197 conditions during the summer $(297 \mathrm{~mm}=2016 ; 222=2017$; compared to $358 \mathrm{~mm}=30$ -

198 year climate average; Figure 2). The temperature for both years were generally similar to

199 the 30-year climate average, with slightly warmer winter temperatures for the months of

200 January $\left(-8.6^{\circ} \mathrm{C}=2016 ;-8.9^{\circ} \mathrm{C}=2017\right.$; compared to $-12.8^{\circ} \mathrm{C}=30$-year climate average $)$

201 and February $\left(-8.9^{\circ} \mathrm{C}=2016 ;-8.6^{\circ} \mathrm{C}=2017\right.$; compared to $-10.6^{\circ} \mathrm{C}=30$-year climate

202 average $)$ and colder summer temperatures for the month of July $\left(18.9^{\circ} \mathrm{C}=2016 ; 17.9^{\circ} \mathrm{C}\right.$

$203=2017$; compared to $19.5^{\circ} \mathrm{C}=30$-year climate average; Figure 2). [Figure 2 near here]

205 Field sampling and analysis

206 Waters from LSC were sampled at five different locations (stations C03, C04 and C05 in

207 the pelagic zone; stations SCE and SCA in the littoral zone; Table 1). Hurons River (HR),

208 Delage Lake (DL), WWTP effluents of Stoneham-and-Tewkesbury (WWTP-ST), City of

209 Lac Delage (WWTP-LD), and 28 small stream tributaries (SSTs; DD, CC, BB, AA, FF,

210 W, Z, GG, U, T, HH, S, R, Q, P, CPLSC18, M, KK, L, K, J, E, OO, H, C, F, G and PP)

211 were sampled at only one location. All sites were sampled every other week from June to

212 October 2016 and an additional six SSTs (IID, IIB, LL, NN, N and A) were sampled

213 from April to October 2017. The HR, DL, WWTP-ST, WWTP-LD and four SSTs (AA,

214 S, K and OO) were sampled once a month from January to March 2017. Groundwater 
$215(\mathrm{GW})$ in private drinking water wells was sampled at five different locations near the

216 shoreline of LSC (GW1, 2, 3, 4 and 5), once in fall 2016 and four times during the period

217 of January-October 2017. At least one precipitation sample per month from June 2016 to

218 October 2017, except for the months of December and January 2017, was taken at the

219 lake outlet; that is at the aforementioned dam location (Figure 1).

220 Six environmental variables were used to estimate the seasonal contributions of

221 the main water sources (SSTs, HR, DL and WWTPs) to LSC: in-situ measured discharge,

222 water oxygen $\left(\delta^{18} \mathrm{O}\right)$ and hydrogen $(\delta \mathrm{D})$ stable isotope composition, total nitrogen $(\mathrm{TN})$,

223 total phosphorus (TP) and fecal coliforms $(\mathrm{Fc})$. Water stable isotopes were also used to

224 estimate the seasonal contribution of GW and precipitation to LSC.

225

226 Discharge

227 The discharge $(\mathrm{n}=50)$ was measured once a month by different methods logistically

228 constrained by flow strength, water depth, stream bed types or pipe configuration. For

229 most stations, it was not possible to use a single method because the flow was too

230 variable from one visit to another. The velocity-area method for the determination of the

231 stream flow of HR and discharge of DL consisted of measuring depth, distance and

232 stream velocity between different cross-sections of the river. The velocity was

233 measured using a current meter (Swoffer model 2100) and the average was obtained for

234 each cross-section. The discharge rate was then derived from the sum of the product of

235 mean velocity, depth and width between cross-sections. When the water level and flow

236 velocity were too low to use a current meter, we used the speed-area method with floats.

237 The velocity was first calculated by measuring the time the float took to travel a fixed 
238 distance, and after the area of that river section was measured. The discharge was then

239 calculated by multiplying the section area by the velocity. When water flow was

240 extremely low, we used the volumetric method. This method consisted of calculating the

241 discharge from the time needed to fill a container of known volume. These latter two

242 methods were used to measure discharge from the SSTs.

244 Water stable isotope composition

245 Water samples were collected in 30-ml, high-density polyethylene bottles at each

246 sampling site (Figure 1). In total, 105 (2016) and 339 (2017) surface water samples, and 4

247 (2016) and 17 (2017) GW samples were collected. Samples of rain and snow were

248 obtained when precipitation events occurred. Rainwater was collected in a plastic pan

249 until enough water was gathered to fill the $30-\mathrm{ml}$ bottles. This took 2 hours or less. Snow

250 samples were collected in Ziploc ${ }^{\circledR}$ bags and once completely melted, the meltwater was

251 transferred into the $30-\mathrm{ml}$ bottles. Samples were stored at $4^{\circ} \mathrm{C}$ prior to analysis at the

252 University of Waterloo Environmental Isotope Laboratory by Off-Axis Integrated Cavity

253 Output Spectroscopy (Berman et al., 2013).

254 Isotope compositions are expressed as $\delta$-values relative to the Vienna Standard

255 Mean Ocean Water (VSMOW) in per mil (\%), such that $\delta_{\text {sample }}=\left(\mathrm{R}_{\text {sample }}-\mathrm{R}_{\mathrm{VSMOW}}\right)$

$256 / \mathrm{R}_{\mathrm{VSMOW}} \times 1000$, where $\mathrm{R}_{\text {sample }}$ and $\mathrm{R}_{\mathrm{VSMOW}}$ are the ratio ${ }^{18} \mathrm{O} /{ }^{16} \mathrm{O}$ or $\mathrm{D} /{ }^{1} \mathrm{H}$ in the sample

257 and VSMOW, respectively. Results of $\delta^{18} \mathrm{O}$ and $\delta \mathrm{D}$ analysis are normalized to $55.5 \%$

258 and $428 \%$, respectively, for Standard Light Antarctic Precipitation (SLAP; Coplen

259 1996). Analytical uncertainties are $\pm 0.2 \%$ for $\delta^{18} \mathrm{O}$, and $\pm 0.8 \%$ for $\delta \mathrm{D}$. 
262 LSC and its source water isotope compositions were first evaluated in $\delta^{18} \mathrm{O}-\delta \mathrm{D}$ space

263 including the Local and Global Meteoric Water Line (LMWL and GMWL) for

264 references. The LMWL $\left(\delta \mathrm{D}=8.58 \times \delta^{18} \mathrm{O}+15.36\right)$ and GMWL $\left(\delta \mathrm{D}=8 \times \delta^{18} \mathrm{O}+10\right.$;

265 Craig, 1961) respectively expresses the local and global linear relationships between the

266 oxygen and hydrogen isotope compositions of precipitation. The $\delta^{18} \mathrm{O}$ and $\delta \mathrm{D}$ values for

267 precipitation typically fall along the GMWL (or LMWL), and their position reflects

268 variability in spatial and seasonal trajectory of the atmospheric vapor contributing to local

269 precipitation (Rozanski et al. 1993). This normally leads to isotopically-depleted winter

270 precipitation and isotopically enriched summer precipitation (Dansgaard 1964).

271 As shown in Figure 3, LSC does not display substantial evidence of evaporative

272 isotopic enrichment. Lake water isotope composition will usually plot along another

273 linear trend called Local Evaporation Line (LEL: Yi et al. 2008; Turner et al. 2010). The

274 LEL typically has a lower slope than the LMWL and GMWL. Lake water isotope

275 compositions in our study plot along and above the GMWL and LMWL, as expected

276 given the fluvial setting. With the absence of evaporation, it is assumed that the measured

277 lake water isotope composition is a straightforward reflection of the varying

278 combinations of water sources. Prior to proceeding with source partitioning, seasonal

279 isotopic ratios for the lake and its water sources (HR, DL, SSTs, WWTPs) were weighted

280 by the discharge. Each $\delta^{18} \mathrm{O}($ and $\delta \mathrm{D})$ value was multiplied by the corresponding

281 discharge, and their sum divided by the sum of the total discharge during that season. For

$282 \mathrm{GW}$ and precipitation, the arithmetic mean of the isotope compositions was used. 
We applied the standard linear mixing model developed by Phillips and Gregg

284 (2003) to determine multiple combinations of multiple source proportions using the

285 IsoSource 1.3.1 program. This model is well suited when the number of contribution

286 sources to a mixture is too large to obtain a unique value, and thus an estimated range of

287 individual contributions $(0 \%-100 \%)$ is provided. These ranges depend on the similarity

288 and position within the mixing polygons of source isotope composition in reference to a

289 mixture. In general, small mass balance tolerance $( \pm 0.1 \%$ of ource proportions of a

290 mixture is considered to have feasible solutions, from which the frequency (histograms)

291 and range $(\%)$ of potential source contributions can be determined.

292 As a linear relationship exists between $\delta^{18} \mathrm{O}$ and $\delta \mathrm{D}$ (Craig 1961) in meteoric

293 water, we assumed that the water source partitioning is the same for both isotopes. We

294 supplied the IsoSource 1.3.1 program with the water isotope compositions of the lake and

295 its water sources, along with the desired source increment $( \pm 1 \%)$ and the mass balance

296 tolerance $( \pm 0.1 \%)$ in order to include all possible contributions. As described by

297 Phillips and Gregg (2003), the program repeatedly calculates each possible combination

298 of source proportions. The predicted isotope composition for the lake water was

299 computed as each combination was generated. These predicted lake water isotope

300 compositions were compared to observed values. If they were equal or within a

301 predetermined mass balance tolerance $( \pm 0.1 \%$ ), they were considered to represent a

302 possible solution and, thus, included in the results. All combinations were represented by

303 histograms with descriptive statistics of the distributions for each source. Within the

304 drawn polygons in $\delta^{18} \mathrm{O}-\delta \mathrm{D}$ space, we assumed that source waters falling closest to that

305 of LSC provided the greatest water contribution. We used the mean value of the 
306 partitioning solution for each water source to estimate the seasonal changes in source

307 contribution to LSC.

308

309 Nutrients and fecal coliforms

310 As previously mentioned, waters from LSC $(n=61)$, SSTs $(n=393), \operatorname{HR}(n=24)$, DL $(n=$

311 27) and WWTP effluents ( $\mathrm{n}=44)$ were sampled at two-week intervals during the two-

312 year sampling period for the measurement of TN, TP and Fc (except Fc not measured in

313 LSC in 2016). The samples were collected in 250-ml high-density polyethylene bottles,

314 and immediately stored in a cooler before taking to the laboratory of Québec City on the

315 same day.

316 Total nitrogen (TN) was obtained by the catalytic oxidation method with a

317 Shimadzu TOC-V $\mathrm{V}_{\mathrm{CPH}}$ NTM-1 instrument. Nitrogenous compounds were oxidized on a

318 platinum catalyzer at $680^{\circ} \mathrm{C}$ under pure oxygen atmosphere, the generated nitric oxide

319 reacted with ozone, and the product analysed by chemiluminescence (Nollet and De

320 Gelder. 2007). Total phosphorus (TP) analysis was conducted with a sensitive automated

321 colorimetric method for phosphate detection using a flow segmented Astoria analyzer.

322 Phosphorous compounds were first digested with persulfate in acidic conditions, and then

323 reacted with molybdophosphoric acid and ascorbic acid to form the molybdenum blue

324 color complex quantified by spectrophotometry (APHA, AWWA, WEF, 2005). The

325 detection limits for phosphorous and nitrogen are $0.08 \mathrm{mg} \mathrm{N} \mathrm{L}^{-1}$ and $2 \mu \mathrm{gP} \mathrm{L}^{-1}$,

326 respectively.

327 The water discharge was used to calculate nutrients and $\mathrm{Fc}$ seasonal mass fluxes

328 to the LSC from the aforementioned sources (i.e., HR, DL, SSTs and WWTPs). The mass 
329 flux for each of water source was estimated using the averaging estimators' method

330 explained in Quilbé et al. (2006). The mass flux was first calculated for each day where

331 both variables were measured by multiplying the concentration with the corresponding

332 discharge on a given day (discharge $\times$ concentration $\times 24 \mathrm{~h}$ ), and the mean monthly mass

333 flux was then calculated for each water source. For SSTs, the mass fluxes of 29 small

334 tributaries were summed over each month. When more than one mass flux was available

335 for any specific SST, the mean was calculated, and this value was then included in the

336 total SSTs monthly mass flux. Seasonal fluxes were obtained by weighting the mean

337 monthly flux (F) by the total number of days in a given season. For example, to obtain

338 the seasonal flux estimation over summer (June, July and August), the weighted summer

339 mass flux was determined as follows: $\left(\mathrm{F}_{\mathrm{Jun}} \times 30+\mathrm{F}_{\mathrm{Jul}} \times 31+\mathrm{F}_{\mathrm{Aug}} \times 31\right) /(30+31+31)$.

\section{$341 \quad$ Results}

\section{Water isotope composition}

343 LSC and its water source isotope compositions were plotted in $\delta^{18} \mathrm{O}-\delta^{2} \mathrm{H}$ space to assess

344 the varying signatures of this hydrological system (Figure 3; Table 1). The isotope

345 composition of LSC and most of its water sources cluster along and above the

346 GMWL/LMWL, indicating the absence of any significant seasonal evaporative isotopic

347 enrichment. WWTP, DL, HR and GW display similar ranges in isotope composition, and

348 are also similar to the LSC signature. However, the isotope composition of SSTs and

349 precipitation span a greater range. Thus, both SSTs and precipitation water characteristics

350 vary from isotopically-enriched to isotopically-depleted lake water sources. The

351 superimposed isotope compositions of LSC and its water sources makes it difficult to 
352 assess the relative contributions of individual sources, thus, a standard linear mixing

353 model was applied to provide mathematical solutions for partitioning these waters. This

354 required a seasonal estimation of the mean isotope composition for LSC water sources.

355 [Table 1 near here] [Figure 3 near here]

356 Water discharges of HR, DL, SSTs, WWTPs were also used to determine amount-

357 weighted mean isotope values, while $\mathrm{GW}$ and precipitation mean isotope compositions

358 were determined arithmetically (Table 2). HR, SSTs and GW presented similar ranges,

359 while WWTPs, DL and rain had slightly more enriched values. Snow (only sampled

360 during winter 2017) had mean isotope values of $-11.2 \%$ for $\delta^{18} \mathrm{O}$ and $-81.9 \%$ for $\delta \mathrm{D}$.

361 [Table 2 near here]

362

363 Source water partitioning

364 For most LSC water sources, results from IsoSource 1.3.1 program modelling generated

365 broad ranges of possible contributions (Figure 4). Figure 4 illustrates mixing polygons for

$366 \delta^{18} \mathrm{O}$ and $\delta \mathrm{D}$ signatures of the six LSC water sources. The histograms associated with

367 each source show the distribution of feasible contributions from each potential source to

368 LSC. Values shown in the boxes cover 1-99 percentile ranges for these distributions.

369 LSC isotope composition fell within the mixing polygons bounded by all sources,

370 indicating plausible contributions from all sources during any given season (although

371 only four sources were characterized for summer 2016).

372 In a first attempt to identify the dominant water sources to LSC, only source

373 contribution ranges exceeding 50\% were considered (Figure 4). With this constraint,

374 water sources HR, GW and SSTs potentially accounted for more than 50\% of LSC waters 
375 during three of the six-time intervals. The dominant contribution by HR occurred during

376 fall $2016(0-72 \%)$ and winter 2017 (5-63\%). The high contribution of HR in summer

3772016 (43-91\%) may be overestimated as only four sources were characterized during that

378 interval. GW exceeded the 50\% contribution threshold during summer 2017 (36-67\%),

379 winter 2017 (0-54\%) and spring 2017 (0-52\%), whereas SSTs exceeded 50\% in fall 2016

380 (0-58\%), fall 2017 (0-52\%) and spring 2017 (16-59\%). Overall, at least one of HR, GW

381 or SSTs was a dominant water source during any given season. DL and WWTP exceeded

$38250 \%$ only in spring 2017 (0-56\% and 0-55\%, respectively). Precipitation never exceeded

383 the $50 \%$ threshold as expected given the small ratio of the lake surface area to the lake

384 watershed area (1:55). [Figure 4 near here]

385 Using only the mean value from the possible range of solutions predicted by

386 IsoSource 1.3.1 program for each water source and season, we estimated seasonal

387 variability in water source contributions (Figure 5). To simplify to the four principal

388 seasons (out of six in this two-year study), we averaged summers 2016 and 2017, and

389 falls 2016 and 2017. The largest seasonal contribution of all sources was estimated for

$390 \mathrm{GW}$, which ranged from $17 \%$ to $53 \%$, with the largest contribution in summer (53\%).

391 The second most important contributor was discharge from the HR, which ranged from

$39212 \%$ to $35 \%$, with the highest contribution occurring in winter $(35 \%)$ and fall $(26 \%)$,

393 followed by SSTs, which ranged from $11 \%$ to $33 \%$, with the highest contribution in

394 spring (33\%). Other contributions were smaller, including those of DL (6-16\%), WWTPs

395 (5-16\%), rain (6-15\%) and snow (8\%), with a maximum contribution in spring for DL

396 (16\%) and WWTPs (16\%), and in fall for rain (15\%). Based on these results, while

397 acknowledging only two years of study, we can rank in decreasing order the annual water 
398 source contributions to LSC as follows: $\mathrm{GW}>\mathrm{HR}>\mathrm{SSTs}>\mathrm{WWTP}>\mathrm{DL}>$

399 Precipitation. [Figure 5 near here]

400

\section{Contribution of pollutants to LSC}

402 The distributions of nutrients and Fc in LSC and its sources are presented in Table 1 and

403 Figure 6. The largest nutrient concentrations were observed in WWTP effluents followed

404 by SST flows during all six seasons studied. The smallest nutrient concentrations were

405 measured in the HR followed by DL. The highest Fc concentrations were measured in

406 SST flows during all six seasons with the exception of spring 2017. The smallest Fc

407 concentrations were observed in DL. Despite some sources being relatively large in

408 nutrients (i.e. WWTPs) and Fc (i.e. SSTs), LSC waters have relatively small

409 concentrations in nutrients and $\mathrm{Fc}$ (on average $0.40 \mathrm{mg} \mathrm{N} \mathrm{L}^{-1}, 13.20 \mu \mathrm{gP} \mathrm{L}^{-1}$ and 13.30

$410 \mathrm{CFU} / 100 \mathrm{ml})$. [Figure 6 near here]

411 The calculated seasonal nutrient and fecal coliform mass fluxes are presented in

412 Table 3 and Figure 7. HR had the highest nutrient mass flux during all seasons (2 - 9467

$413 \mathrm{~kg} \mathrm{~N} \mathrm{~d}^{-1}$ and $\left.46-662 \mathrm{~kg} \mathrm{P} \mathrm{d}^{-1}\right)$ followed by SSTs $\left(90-3438 \mathrm{~kg} \mathrm{~N} \mathrm{~d}^{-1}\right.$ and $11-76 \mathrm{~kg} \mathrm{P} \mathrm{d}^{-}$

41 $^{1}$ ) with maximum values in fall 2016 (TP) or fall 2017 (TN). The WWTP-ST effluent

415 nutrient mass flux, which is discharged in the HR a few kilometers upstream, was also

416 important, particularly TN mass flux (120 - $992 \mathrm{~kg} \mathrm{~N} \mathrm{~d}^{-1}$ and 2.7 - $\left.26 \mathrm{~kg} \mathrm{P} \mathrm{d}^{-1}\right)$. WWTP-

417 LD effluent and DL had the smallest nutrient flux among LSC sources (WWTP-LD: 63 -

$418234 \mathrm{~kg} \mathrm{~N} \mathrm{~d}^{-1}$ and $1-13 \mathrm{~kg} \mathrm{P} \mathrm{d}^{-1}$; DL: $35-71 \mathrm{~kg} \mathrm{~N} \mathrm{~d}^{-1}$ and $1-3 \mathrm{~kg} \mathrm{P} \mathrm{d}^{-1}$ ). Fecal coliform

419 mass flux was the smallest for HR during three seasons (summer 2016, spring 2017 and

420 summer 2017; reaching up to $221432 \times 10^{9} \mathrm{CFU} \mathrm{d}^{-1}$ ) and for SSTs during two seasons 
421 (falls 2016 and 2017, up to $12286 \times 10^{9} \mathrm{CFU} \mathrm{d}^{-1}$ ). In general, WWTP effluents had lower

422 fecal coliform mass fluxes than HR and SSTs (WWTP-ST: 5-802 x109 CFU d-1; WWTP-

423 LD: 0.7-78 x10 ${ }^{9} \mathrm{CFU} \mathrm{d}^{-1}$ ), with maximum values reached in winter 2017 (WWTP-ST) or

424 spring 2017 (WWTP-LD). DL had the smallest fecal coliform mass flux (4-51 x10 ${ }^{9}$ CFU

$425 \mathrm{~d}^{-1}$ ) during all seasons. [Table 3 near here]

426 [Figure 7 near here]

\section{Discussion}

429 A six-season snapshot of LSC and its water source isotope composition provides insights

430 into the hydrological regime of this lake. LSC and its water sources span a narrow range

431 of isotope compositions and do not display any evaporative enrichment, supporting the

432 known fluvial nature of this lake with a relatively short residence time. Some water

433 source isotope compositions plotted above the GMWL/LMWL, reflecting the importance

434 of precipitation from local moisture recycling (Clark and Fritz 1997; Froehlich et al.

435 2008; Wenling et al. 2017).

436 Using the mean values from the possible solution ranges and the threshold value

437 set at $50 \%$, we were able to estimate that HR is not the only dominant water source as

438 previously evaluated (APEL 2014a and b). Water sources of LSC were dominated by

439 SSTs and HR during the spring and fall high flow season, and GW and HR during the

440 low flow periods of summer and winter (Figure 5). Moreover, the contribution of HR

441 might be overestimated; that is, it could even be lower considering that some sources

442 (e.g., GW) were not included in the estimate of summer 2016, and only four SSTs were

443 sampled in winter 2017 due to logistical constrains (Section 2). Our results also indicate 
444 that WWTPs, DL and precipitation never became dominant contributors of water to LSC.

445 Although their volumetric contributions were relatively stable throughout the year, their

446 relative contributions were in all likelihood largest during either spring (WWTPs and DL)

447 or fall (Rain; Figure 5). It is important to acknowledge that for most of the water sources,

448 only broad ranges of possible contributions to LSC could be determined. There are two

449 reasons for this outcome. First, there was a high degree of similarity between LSC and

450 water source isotopic signatures, making the mixing polygons very narrow (Figure 4).

451 This overlap is likely linked to the similar moisture source among waters, and to the

452 absence of any effects caused by variations in topography or surface water temperature

453 within the watershed. Second, the lake isotopic signature fell near the centre of the

454 polygons (e.g., in falls 2016 and 2017), and, thus, was apparently composed of

455 approximately equal contributions of these potential sources (e.g., more diffuse solutions)

456 as explained in Phillips and Gregg (2003).

457 Based on our results, the high GW contribution to LSC water budget in summer

458 must have played a significant role in buffering the evaporation and the lake water level

459 drawdown, as lake water isotope composition demonstrated negligible evaporative

460 enrichment. While Quebec City relies on the LSC during summer, the high-water demand

461 season, the lake relies on groundwater supply to maintain its water level. Thus, additional

462 investigations on this source are crucial to gain a comprehensive knowledge of

463 groundwater quantity, quality and seasonal discharge enabling a more sustainable

464 management of this drinking water reservoir in the coming years and in response to

465 climate change. 
Our results showed that SSTs are one of the three main contributors to the LSC

467 water budget (Figure 5) despite of their small drainage areas (Figure 1) and overall

468 discharge (Table 1). During spring, their contributions were twofold and relatively

469 greater when compared to other sources (Figure 5). Meanwhile, during the dry summer

470 and winter seasons, the contribution of SSTs decreased to less than about one-third of the

471 HR (winter 2017) and one-sixth of the GW (summer 2017). These results suggest that

472 SSTs are dominantly rain-fed, and that their discharge is in inherently governed by

473 fluctuations in precipitation amount, making them more variable on a seasonal basis,

474 unlike the steady and controlled discharge of WWTP effluents. It is noteworthy that

475 almost 200 single housing units with septic installations are drained by these small

476 streams, which makes them an important non-point source of pollutants to LSC, and

477 comparable to WWTPs as both are domestic wastewater sources to the lake (see below).

478 Therefore, the cumulative impact from changes in precipitation-driven discharge and

479 densification of the septic installations through housing development will likely influence

480 the water quality of these small streams and ultimately that of LSC (Moore et al. 2003).

481 To gauge the amplitude of these drivers, long-term monitoring of individual small

482 streams to gauge the amplitude of these drivers will be critically needed to assess, for

483 example, the impacts of deforestation, groundwater abstraction by sewage contraction or

484 housing development.

485 To reduce excessive nutrient mass loadings causing lake eutrophication, the

486 assessment of both non-point and point sources at the watershed scale is required (Moore

487 et al. 2003). Most of the phosphorus and nitrogen loading to LSC were transiting through

488 the HR (combined sources of WWTP-ST and septic installations) and SSTs, indicating 
489 the greater nutrient contributions from areas with higher number of individual septic

490 installations through diffuse runoff when compared to that from WWTP effluents (Figure

491 7). The relatively lower nutrient fluxes estimated for spring 2017 through SST flows

492 (approximately 4\% of the seasonal budget) may be linked to the under-sampling of the

493 small tributaries $(n=9)$ in April, which covered less than $43 \%$ of the SST watersheds.

494 Most of SSTs were still either frozen or were difficult to access. Most importantly, the

495 HR drains a large number of individual septic installations, approximately 2 700, septic

496 installations in the watershed of this large river. Therefore, our estimate of the relative

497 importance of individual septic installations draining domestic wastewaters through SSTs 498 is conservative.

499 The HR watershed is heavily impacted by human activities such as deforestation, 500 urbanization, erosion and recreational tourism (APEL 2014b). All of these activities have 501 the potential to contribute excessively to nutrient and fecal coliform fluxes (Smol 2008;

502 Wetzel 2011). Even though HR has nearly 10-fold mass fluxes of nutrients and fecal

503 coliforms than those of the WWTP-ST effluent, due to its higher discharge, the high fecal

504 coliform mass flux from WWTP-ST in winter 2017 (Figure 7) is not negligible. These

505 exceptionally large fecal coliform values could be linked to the recreational activities

506 occurring at the nearby upstream large ski resort over the winter period, which is

507 connected to the WWTP-ST, and the lower ambient temperature of the aerated lagoons

508 could be responsible for an insufficient treatment when compared to the performance

509 during the other seasons (Stein and Hook 2010). The seasonally-driven increase in

510 population within a watershed represents an important factor to consider when estimating

511 the overall source-specific nutrient and pollutant contributions. 
The DL (55 individual septic installations; Table 1) and WWTP-LD (connecting

513600 inhabitants) showed the smallest nutrient and fecal coliform contributions to LSC.

514 The small community size and low discharge, with the occasional LSC inflow to DL

515 during high-flow seasons (waters flowing from LSC to DL instead of the normally

516 opposite flow direction), are the reasons why these two water sources make a small

517 contribution of pollutants (APEL 2014b), as compared to the WWTP-ST ( 5000

518 inhabitants and close to 2700 septic installations) and SSTs (ca. 200 septic installations).

519 Moreover, the WWTP-LD effluent runs into a marsh located in the northern basin of LSC

520 (Figure 1) that is most likely filtering excess nutrients and Fc (VeHRoeven and

521 Meuleman 1999; Knight et al. 2000; APEL 2014b). However, a more specific

522 investigation would be needed to evaluate the impact of the WWTP-LD during winter

523 and fall when filtration by senescent marsh plants is inefficient.

524 The largest nitrogen, phosphorous and fecal coliform mass fluxes from SST

525 runoff were detected during high-flow periods in the fall. The precipitation during fall of

526 both studied years were above the 1981-2010 normal (notably in October; Figure 2) and

527 are likely to have caused particularly high inputs of pollutants and nutrients over these

528 specific years. This seasonal increase in stream flow has been identified in other studies

529 (Nash and Gleick 1991; Rowe et al. 1994; Zhang et al. 2001; Barnett et al. 2005). On the

530 other hand, the higher precipitation during spring was not associated with exceptionally

531 high nutrient and fecal coliform mass fluxes (Figures 2 and 7). Spring flow depends on

532 water equivalent of the snowpack and on the local warming temperature rates that

533 directly influence lake ice-free conditions (Barnette et al. 2005; Ouranos 2015). Higher

534 winter temperatures, increasing precipitation, are inducing an earlier spring freshet and 
535 higher peak flow in recent years (Ouranos 2015). Winter temperatures were warmer

536 during our study period compared to the climate normal (January-February; Figure 2),

537 possibly shifting the spring SST flows earlier than anticipated for the sampling campaign.

538 Consequently, the peak spring flow might not have been entirely captured,

539 underestimating its importance in the overall budget. Changes in the seasonal

540 precipitation regime and temperature trends have important implications on stream flow

541 dynamics (IPCC 2014), and therefore on changes in the SST runoff and their mass flux

542 potentials. The urbanization of the SST watersheds, especially in the southern basin of

543 LSC, may have amplified the effects of increased runoff and ensuing contributions of

544 pollutants due to the associated rise in impermeable surfaces (e.g., asphalted). The SST

545 watersheds with higher urbanisation $(\mathrm{HH}, \mathrm{N}, \mathrm{J}, \mathrm{E}, \mathrm{H}, \mathrm{F}, \mathrm{A}, \mathrm{G}$ and PP), indeed, had larger

546 concentrations of nutrients and Fc (Table 1).

\section{Conclusion}

549 Waters of Lake St. Charles (LSC) and its main water sources were sampled for two

550 consecutive years covering six seasons (summer 2016 - fall 2017). Oxygen and hydrogen

551 stable isotope signatures, and seasonal mass fluxes of nutrients and fecal coliforms, using

552 stream flow and concentration measurements, were used to estimate the seasonal

553 contributions of water to the lake. The contribution of the different water sources to LSC

554 varied seasonally, the most important being GW, HR and SSTs followed by WWTP, DL

555 and Precipitation (GW $>$ HR $>$ SSTs $>$ WWTP $>$ DL $>$ Precipitation).

556 The major contributors of nutrients to LSC were HR, SSTs and WWTP-ST

557 effluents. During fall, nutrient and fecal coliform mass fluxes from SSTs were highly 
558 significant and triggered by large amounts of precipitation and increased stream flow.

559 Nearly 200 septic installations were included in the study, focusing on the area drained

560 by the SSTs (i.e., 34 small stream tributaries). The septic installations in the HR

561 watershed were not included in this study. These sources could potentially represent a

562 greater input of nutrients and fecal coliform loadings to LSC, depending on the efficiency

563 of natural degradation (i.e., of $\mathrm{Fc}$ ) and sedimentation (P) along the hydrological pathways

564 and influenced by the transition time. WWTP effluents (ST and LD) remain an important

565 vector of pollutants when assessing lake water quality and sustainability (Vandenberg et

566 al. 2005). However, their contributions of pollutants remained less important compared to

567 those of individual septic installations within the lake watershed. The discharge of

568 WWTP effluents is relatively constant and controlled, unlike the naturally fluctuating

569 seasonal discharge of small stream flows.

$570 \quad$ Our results indicate that the management of this drinking water reservoir should

571 focus on controlling the excessive nutrients and fecal coliform loadings from the

572 widespread diffused runoff associated with individual septic installations within the LSC

573 hillslopes and sub-watersheds (i.e., SST watersheds). Given the fact that the LSC is

574 experiencing signs of eutrophication, HR and SST watersheds need to be regulated and

575 carefully managed as they have the potential to increase the current trophic state of the

576 lake. Management should deal with problems associated with residential area

577 development. The construction of a sewage network to connect old and new residential

578 and commercial buildings to the main Quebec City sewer system to minimize the effect

579 of diffuse runoff should be carefully considered. Changes in amount of seasonal

580 precipitation amount linked to climate change and the accelerated urbanization of the 
581 urban-rural fringe have the potential to accelerate eutrophication of this already fragile

582 lake ecosystem. Mitigation strategies to eutrophication involve complex socioeconomic

583 issues, but a reduction at the source is clearly the best alternative for sustainable lake

584 management. This would unequivocally involve reducing the number of septic

585 installations within the LSC watershed by connecting these to the Quebec City sewer

586 networks and installing sewer systems in anticipation of future residential development.

587 This is likely to be socioeconomically beneficial in the long-term.

589 Acknowledgments

590 Many thanks to employees of APEL for water sampling, and to those of the Water

591 Quality Division of Quebec City for their assistance in the laboratory. A special thanks to

592 James Telford who helped with the stable isotope analyses. This work would not have

593 been possible without the shared financial support from a Mitacs Elevation Postdoctoral

594 Fellowship and APEL. 


\section{References}

596

597

598

599

600

601

602

603

604

605

606

607

608

609

610

611

612

613

614

$615 \bullet$

616

617

618

619

620

621

622

623

624

625

626

627

628

629

630

631

632

633

634

635

636

637

638

639

APEL (1981). Étude descriptive du bassin versant de Lac Saint-Charles, Association du Lac Saint-Charles, $110 \mathrm{p}$.

APEL (2012). Rapport d'étape sur le suivi des cyanobactéries et de l'état trophique du lac Saint-Charles en 2011, Association pour la protection de l'environnement du lac Saint-Charles et des Marais du Nord, Québec, 143 p.

APEL (2014a). Diagnose du lac Saint-Charles, Mémoire. Association pour la protection de l'environnement du lac Saint-Charles et des Marais du Nord, 43 p.

APEL (2014b). Diagnose du lac Saint-Charles, rapport final. Association pour la protection de l'environnement du lac Saint-Charles et des Marais du Nord, $519 \mathrm{p}$.

APEL (2019) Diagnose du lac Saint-Charles - 2016. Association pour la protection de l'environnement du lac Saint-Charles et des Marais du Nord, Québec, 377 pages.

APHA, AWWA \& WEF (2005). Standard Methods for Examination of Water and Wastewater, 21st ed. Washington D.C.

Aravena, R. Evans, M.L. \& Cherry, J.A. (1992). Stable isotopes of oxygen and nitrogen in source idetification of nitrate from septic systems. Ground water, 31(2): 180-186. doi: 10.1111/j.1745-6584.1993.tb01809.x.

Arnade, L.J. (1999). Seasonal correlation of well contamination and septic tank distance. Ground water, 37(6): 920-923. doi:10.1111/j.1745-6584.1999.tb01191.x.

Barnett, T.P., Adam, J.C., \& Lettenmaier, D.P. (2005). Potential impacts of a warming climate on water availability in snow-dominated regions. Nature Reviews, 438(7066): 303-309. doi:10.1038/nature04141.

Berman, E.S.F., Levin, N.E., Landais, A., Li, S. \& Owano, T. (2013). Measurement of $\delta^{18} O, \delta^{17} \mathrm{O}$, and ${ }^{17} \mathrm{O}$-excess in Water by Off-Axis Integrated Cavity Output Spectroscopy and Isotope Ratio Mass Spectrometry. Analytical Chemistry, 85:10392-10398. doi:10.1021/ac402366t.

Clark, I. and Fritz, P. (1997). Environmental Isotopes in Hydrogeology. CRC Press/Lewis Publishers, Boca Raton, 328 pp.

Coplen, T.B. (1996). New guidelines for reporting stable hydrogen, carbon, and oxygen isotope - ratio data. Geochim. Cosmochim. Acta., 60: 3359-3360. doi:10.1016/0016-7037(96)00263-3.

Craig, H. (1961). Isotopic variations in meteoric waters. Science 133, 1702-1703. 
640
Dansgaard, W. (1964). Stable isotopes in precipitation. Tellus XVI. doi: 10.3402/tellusa.v16i4.8993. doi:10.1111/j.2153-3490.1964.tb00181.x.

Environemnt Canada (2017). National Climate Data and Information Archive. http://climat.meteo.gc.ca/historical_data/search_historic_data_f.html.

Froehlich, K., Kralik, M., Papesch, W., Rank, D., Scheifinger, H., \& Stichler, W. (2008). Deuterium excess in precipitation of Alpine regions - Moisture recycling. Isotopes in Environmental and Health Studies, 44(1): 61-70. doi:10.1080/10256010801887208

IPCC (2014). Climate Change 2014: Synthesis Report. Contribution of Working Groups I, II and III to the Fifth Assessment Report of the Intergovernmental Panel on Climate Change [Core Writing Team, R.K. Pachauri and L.A. Meyer (eds.)]. IPCC, Geneva, Switzerland, $151 \mathrm{pp}$.

Knight, R.L., Payne Jr., V.W.E., Borer, R.E., Clarke Jr., R.A. \& Pries, J.H. (1999). Constructed wetlands for livestock wastewater management. Ecological Engineering, 15(1-2): 41-55. doi: 10.1016/S0925-8574(99)00034-8.

APEL (2019). Étude sédimentaire du lac Saint-Charles (Québec). In Diagnose du lac Saint-Charles - 2016. Association pour la protection de l'environnement du lac Saint-Charles et des Marais du Nord, Québec, 377 pages.

Légaré, S. (1997). L'eutrophisation des lacs : le cas du lac Saint-Charles. Naturaliste Can., 121: 65-68.

Légaré, S. (1998). Étude limnologique du lac Saint-Charles. Rapport GREPAUL 98238, Université Laval, Sainte-Foy (Québec). 106 p.

Ministère du Développement durable, de l'Environnement et des Parcs (MDDEP; 2008). Guide technique, Captage d'eau souterraine pour des résidences isolées. Service de l'aménagement et des eaux souterraines de la Direction des politiques de l'eau.

Moore, J.W., Schindler, D.E., Scheuerell, M.D., Smith, D., \& Frodge, J. (2003). Lake Eutrophication at the Urban Fringe, Seattle Region, USA. AMBIO: A Journal of the Human Environment, 32(1): 13-18. doi:10.1579/0044-7447-32.1.13.

Narancic, B., Wolfe, B.B., Pienitz, R., Meyer, H., \& Lamhonwah, D. (2017). Landscapegradient assessment of thermokarst lake hydrology using water isotope tracers. Journal of Hydrology, 545: 327-338. doi:10.1016/j.jhydrol.2016.11.028.

Nash, L. \& Gleick, P.H. (1991). Sensitivity of streamflow in the Colorado basin to climatic changes. Journal Of Hydrology, 125: 221-241. doi:10.1016/00221694(91)90030-L.

Nollet, L.M.L. \& De Gelder, L.S.P. (2007) Handbook of Water Analysis. 2nd Edition, 
686

687

688

689

690

691

692

693

694

695

696

697

698

699

700

701

702

703

704

705

706

707

708

709

710

711

712

713

714

715

716

717

718

719

720

721

722

723

724

725

726

727

728

729

730

731

CRC Press, Boca Raton. 995 p.

Phillips, D.L., \& Gregg, J.W. (2003). Source partitioning using stable isotopes : coping with too many sources, Oecologia, 136: 261-269. doi:10.1007/s00442-003-1218-3.

Ptacek, C.J. (1998). Geochemistry of a septic-system plume in a coastal barrier bar, Point Pelee, Ontario, Canada. Journal of Contaminant Hydrology, 33(3-4): 293312. doi:10.1016/S0169-7722(98)00076-X.

Ritchot, G., Mercier, G. \& Mascolo, S. (1994). L'étalement urbain comme phénomène géographique : l'exemple de Québec. Cahiers de géographie du Québec, 38 (105), 261-300. https://doi.org/10.7202/022451ar.

Robertson, W.D., Shiff, S.L. \& Ptacek, C.J. (1998). Review of phosphate mobility and persistence in 10 septic system plumes. Ground water, 36(6): 1000-1010. doi :10.1111/j.1745-6584.1998.tb02107.x.

Rozanski, K., Araguas-Araguas, L. \& Gonfiantini, R. (1993). Isotope patterns in modern global precipitation. Science 80: 258, 981-985. doi:10.1029/GM078p0001.

Rowe, C.M., Kuivinen, K.C., \& Flores-Mendoza, F. (1994). Sensitivity of streamflow to climate change: a case study for Nebraska. Great Plains Research, 4(1): 27-49

Ouranos (2015). Vers l'adaptation. Synthèse des connaissances sur les changements climatiques au Québec. Partie 1 : Évolution climatique au Québec. Édition 2015. Montréal, Québec: Ouranos, 114 p.

Smol, J.P. (2008). Pollution of Lakes and Rivers: A Paleoenvironmental Perspective. 2nd edition. Wiley-Blackwell Publishing, Oxford, 383 pp,

Statistics Canada, Environment Accounts and Statistics Division (2011). Survey of drinking water plants and households and the environment survey. https://www150.statcan.gc.ca/n1/pub/16-403-x/16-403-x2013001-eng.htm. (accessed December 2018).

Stein, O.R. \& Hook, P.B. (2010). Temperature, plant, and oxygen: How does season affect constructed wetland performance? Journal of Environmental Science and Health, 40(6-7): 1331-1342. doi:10.1081/ESE-200055840.

Tondu, J-M.E., Turner, K.W., Wolfe, B.B., Hall, R.I., Edwards, T.W.D. \& McDonald, I. (2013). Using water isotope tracers to develop the hydrological component of a long-term aquatic ecosystem monitoring program for a northern lake-rich landscape. Arctic, Antarctic, and Alpine Research, 45(4): 594-614. doi : 10.1657/1938-4246-45.4.594.

Tremblay, R., Légaré, S., Pienitz, R., Vincent, W.F., \& Hall, R.I. (2002). Étude 
paléolimnologique de l'histoire trophique du lac Saint-Charles, réservoir d'eau potable de la communauté urbaine de Québec. Revue des sciences de l'eau, 4(2001): 489-510. doi:10.7202/705429ar.

Tremblay, R., \& Pienitz, R. (2015). Caractéristiques limnologiques de 56 lacs du Québec méridional en lien avec l'état trophique. Revue des sciences de l'eau, 28(2): 139. doi:10.7202/1032295ar.

Turner, K.W., Wolfe, B.B., \& Edwards, T.W.D. (2010). Characterizing the role of hydrological processes on lake water balances in the Old Crow Flats, Yukon Territory, Canada, using water isotope tracers, Journal of Hydrology, 386: 103117. doi:10.1016/j.jhydrol.2010.03.012

Vandenberg, J.A., Ryan, M.C., Nuell, D.D. \& Chu, A. (2005). Field evaluation of mixing length and attenuation of nutrients and fecal coliform in awastewater effluent plume. Environmental Monitoring and Assessment, 107: 45-57. doi:10.1007/s10661-0052020-y.

VeHRoeven, J.T.A. \& Meuleman, A.F.M. (1998). Wetlands for wastewater treatment: Opportunities and limitations. Ecological Engineering, 12: 5-12. doi:10.1016/S0925-8574(98)00050-0.

Wenling A., Shugui, H., Qiong, Z., Wangbin, Z., Shuangye, W., Hao, X., Hongxi, P., Yetang, W. \& Yaping, L. (2017). Enhanced Recent Local Moisture Recycling on the Northwestern Tibetan Plateau Deduced From Ice Core Deuterium Excess Records. Journal of Geophysical Research: Atmospheres, 122(23): 541-556. doi:10.1002/2017JD027235.

Wetzel, R.G. (2001). Limnology: Lake and river ecosystems. San Diego: Academic Press, 1006p.

Wernick, B.G., Cook, K.E., \& Schreier, H. (1998). Land-use and streamwater nitrate-N dynamics in an urban-rural fringe watershed. Journal of the American watrer resources association, 34(3): 639-650. doi: 10.1111/j.1752-1688.1998.tb00961.x.

Wilhelm, S.R., Schiff, S.L. \& Cherry, J.A. (1996). Biogeochemical evolution of domestic waste water in septic systems: 1. Conceptual model. Ground water, 32(6): 905-916. doi:10.1111/j.1745-6584.1994.tb00930.x.

Zhang, X., Harvey, K.D., Hogg, W.D., \& Yuzyk, T.R. (2001). Trends in Canadian streamflow. Water Resources Reserche, 37(4): 987-998. doi:10.1029/2000WR900357. 


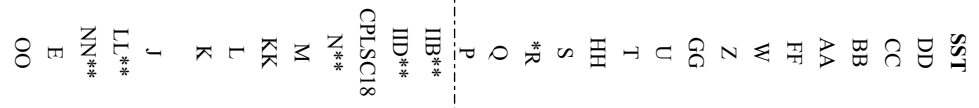

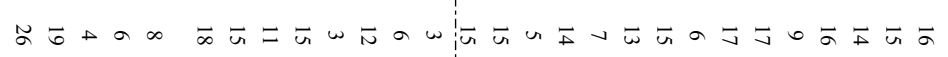

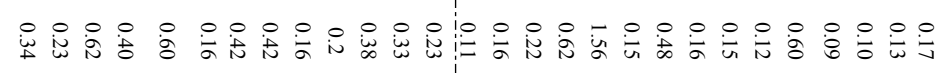

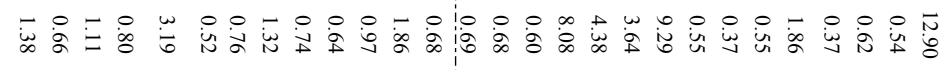

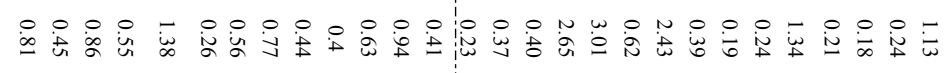

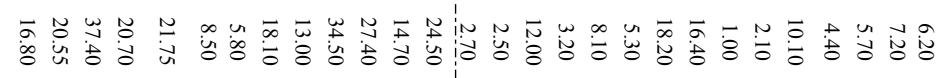

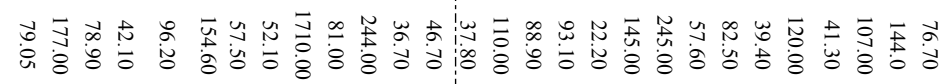

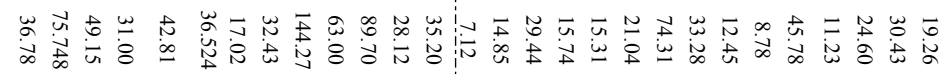

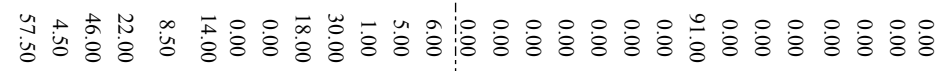

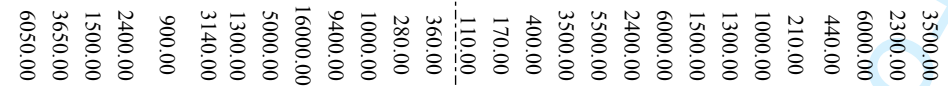

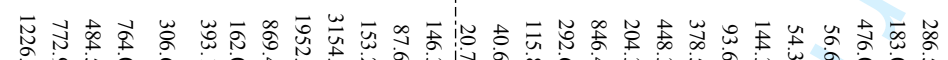

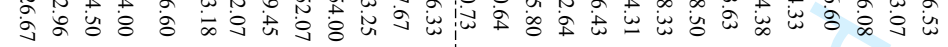

絮, . . .

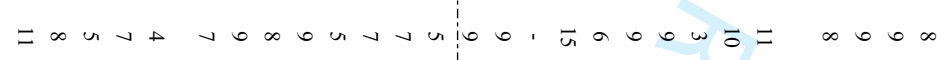

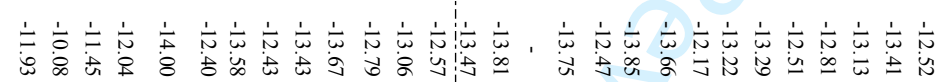

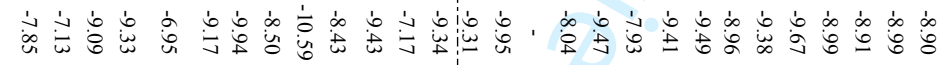

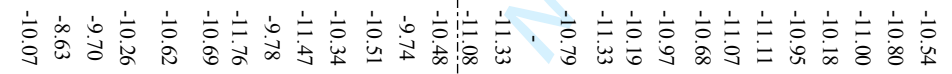

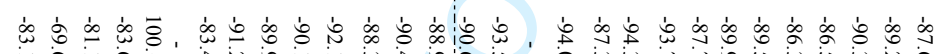

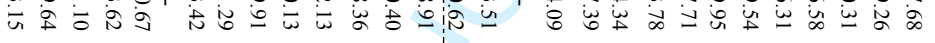

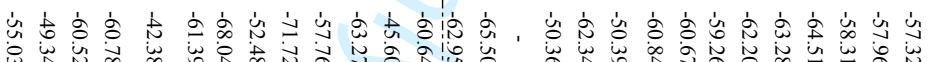

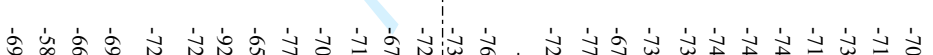

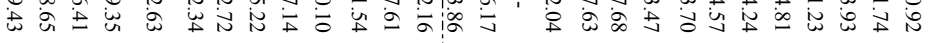

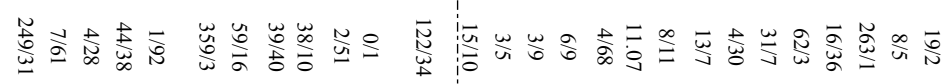

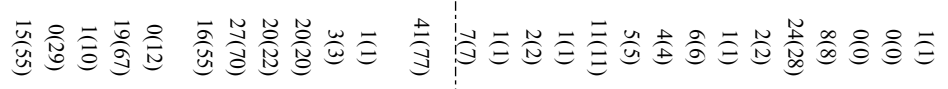

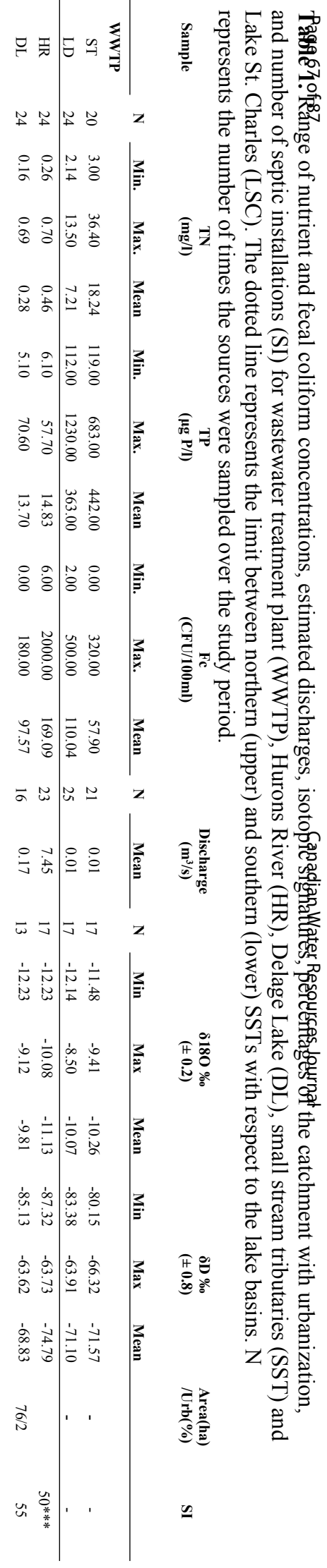


Table 2. Amount-weighted water isotope compositions using the discharges of six lake water sources: Hurons River (HR), small stream tributaries (SST), groundwater (GW), wastewater treatment plant (WWTP), Delage Lake (DL) and precipitation (rain + snow).

\begin{tabular}{|c|c|c|c|c|c|c|c|c|c|c|c|c|}
\hline \multirow[t]{2}{*}{ Sample } & \multicolumn{2}{|c|}{ Summer 2016} & \multicolumn{2}{|c|}{ Fall 2016} & \multicolumn{2}{|c|}{ Winter 2017} & \multicolumn{2}{|c|}{ Spring 2017} & \multicolumn{2}{|c|}{ Summer 2017} & \multicolumn{2}{|c|}{ Fall 2017} \\
\hline & $\delta^{18} \mathrm{O}$ & $\delta \mathrm{D}$ & $\delta^{18} \mathrm{O}$ & $\delta \mathrm{D}$ & $\delta^{18} \mathrm{O}$ & $\delta \mathrm{D}$ & $\delta^{18} \mathrm{O}$ & $\delta \mathrm{D}$ & $\delta^{18} \mathrm{O}$ & $\delta \mathrm{D}$ & $\delta^{18} \mathrm{O}$ & $\delta \mathrm{D}$ \\
\hline WWTP & -10.14 & -70.7 & -9.42 & -66.54 & -11.06 & -74.67 & -11.51 & -80.08 & -10.36 & -79.12 & -9.84 & -68.95 \\
\hline HR & -11.1 & -74.82 & -10.24 & -68.18 & -12.07 & -79.51 & -12.18 & -86.35 & -10.84 & -73.01 & -10.23 & -64.14 \\
\hline DL & & & -9.25 & -63.8 & -9.83 & -68.01 & -11.59 & -80.68 & -9.45 & -68.17 & -9.13 & -66.87 \\
\hline SSTs & -10.12 & -68.39 & -9.52 & -64.72 & -11.07 & -75.32 & -12.77 & -86.29 & -10.24 & -70.08 & -9.27 & -62.12 \\
\hline $\mathrm{GW}^{*}$ & & & -12.08 & -81.3 & -11.86 & -81.33 & -11.46 & -78.58 & -12.08 & -81.51 & -11.84 & -80.67 \\
\hline Rain & -8.87 & -58.92 & -8.93 & -56.52 & & & -9.08 & -59.32 & -9.17 & -62.99 & -9.17 & -62.49 \\
\hline Snow & & & & & -11.22 & -81.89 & & & & & & \\
\hline
\end{tabular}

* Not weighted 


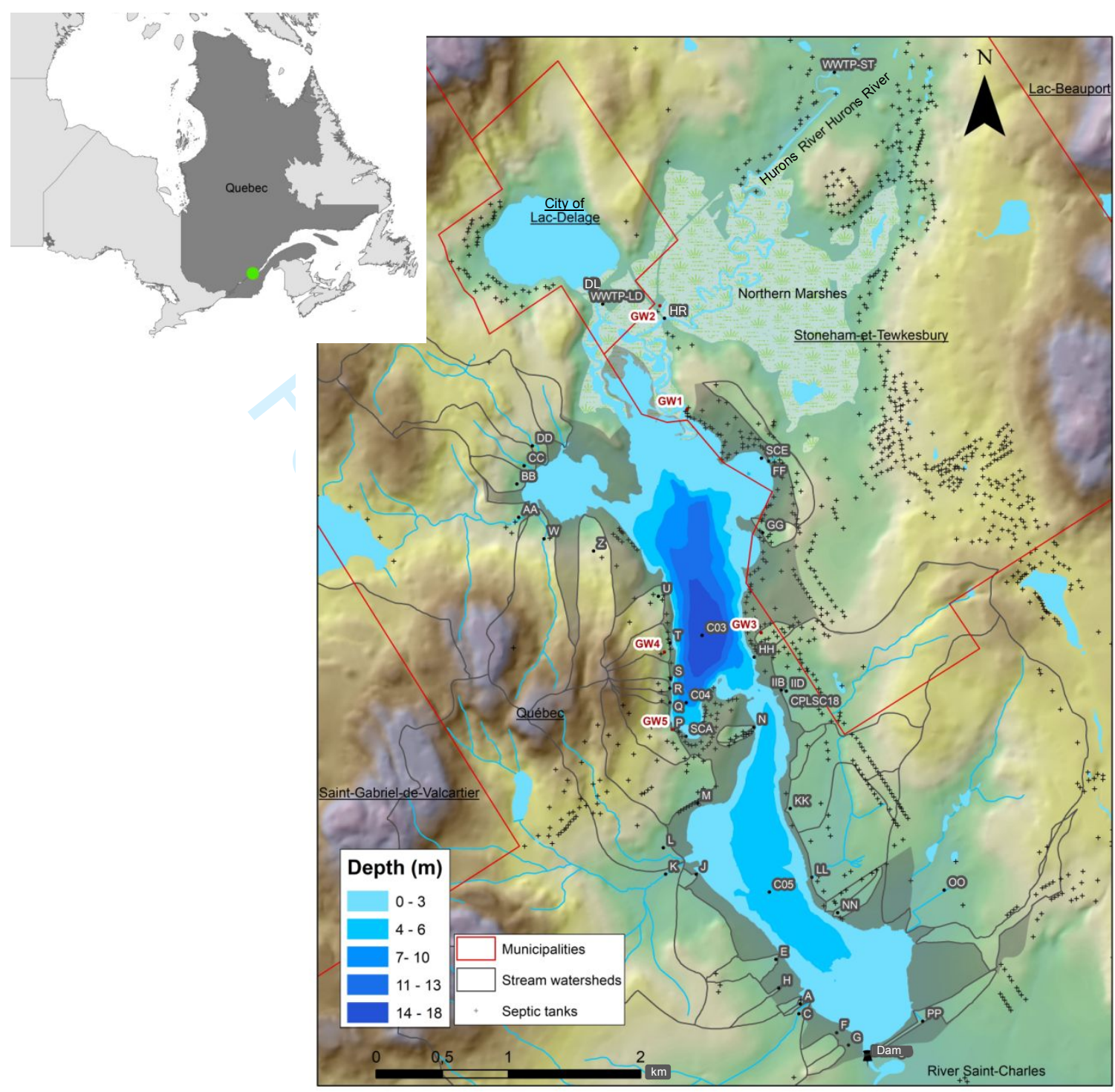

Figure 1. The Lake St. Charles along with location of municipal boundaries (red line), 38 surface water and 5 ground water (GW) sampling stations, bathymetry of Lake St. Charles and septic installation locations. The shaded area represents diffuse (i.e. hillslope) runoff to Lake St. Charles. Small stream catchments are outlined for each stream tributary (grey line). The sampling points WWTP-LD and WWTP-ST represent the wastewater treatment plan effluents of City of Lac Delage and Stoneham-and-Tewkesbury, respectively. 

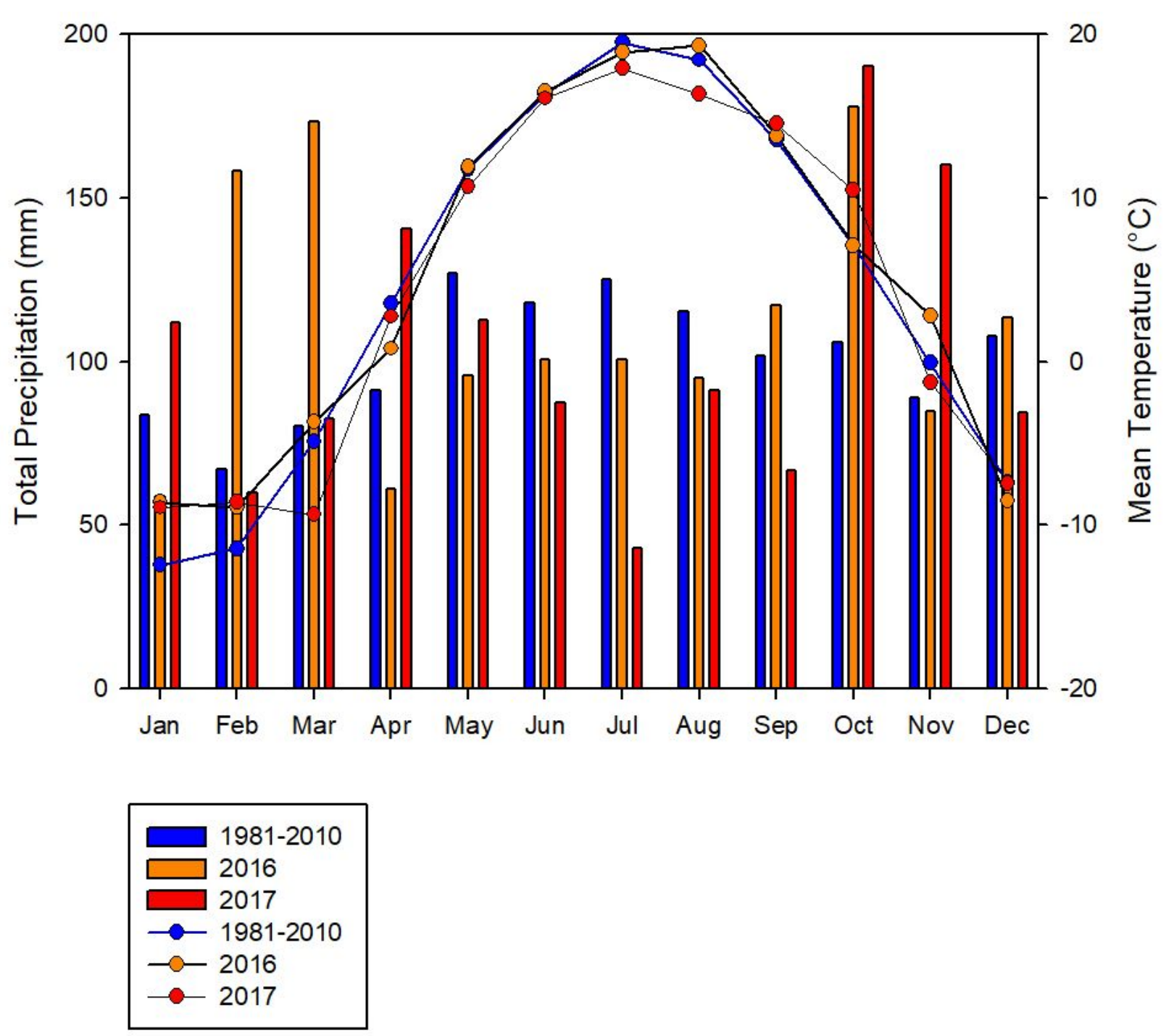

Figure 2. Mean monthly air temperature $\left({ }^{\circ} \mathrm{C}\right.$; lines) and total monthly precipitation (mm; vertical bars) recorded at the Jean Lesage international airport weather station (Station ID: 701S001) for year 2016 and 2017 compared to the 1981-2010 period (Environment Canada, 2017). 

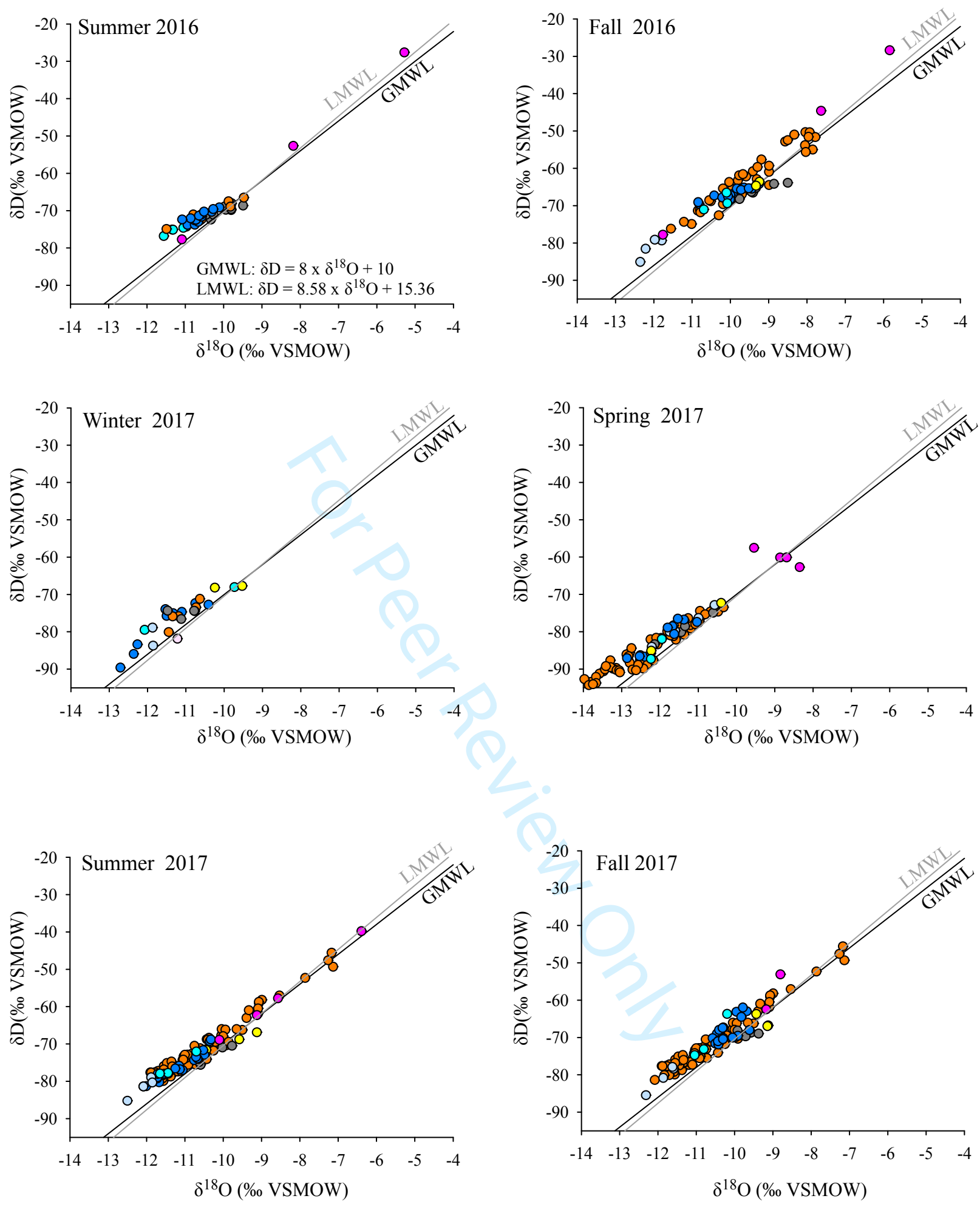

Figure 3. Isotope compositions of Lake St. Charles (LSC; dark blue) and of inflows: Hurons River (HR, light turquoise), small stream tributaries (SST, orange), wastewater treatment plant (WWTP, grey) effluents, groundwater (GW, light blue), Delage Lake (DL, yellow), and precipitation (dark pink for rain and light pink for snow) relative to the Local and Global Meteoric Water Line (LMWL and GMWL). The seasons were defined by astronomical calendar following the equinoxes and solstices. 

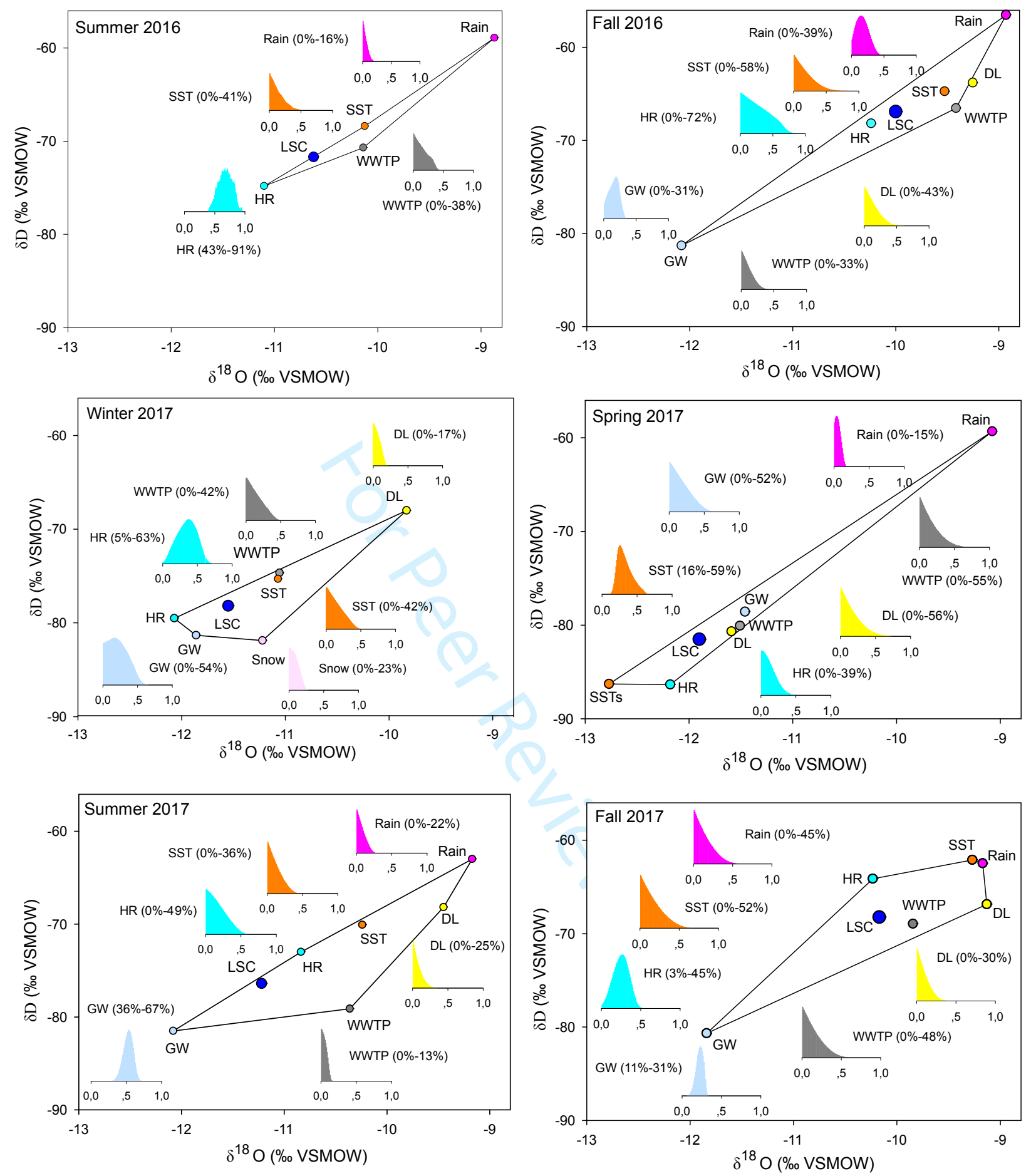

Figure 4. Mixing polygons for average values of $\square{ }^{18} \mathrm{O}$ and $\square \mathrm{D}$ of six sources: Hurons River (HR turquoise), small stream tributaries (SST orange), wastewater treatment plants (WWTP grey), Delage Lake (DL yellow), groundwater (GW light blue) and precipitation (rain dark pink and snow light pink) for Lake St. Charles (LSC dark blue). The histograms show the distribution of possible contributions from each source to the lake. Values shown in the boxes depict the 1-99 percentiles for these contributions. For the summer 2016, only four sources could be characterized. 


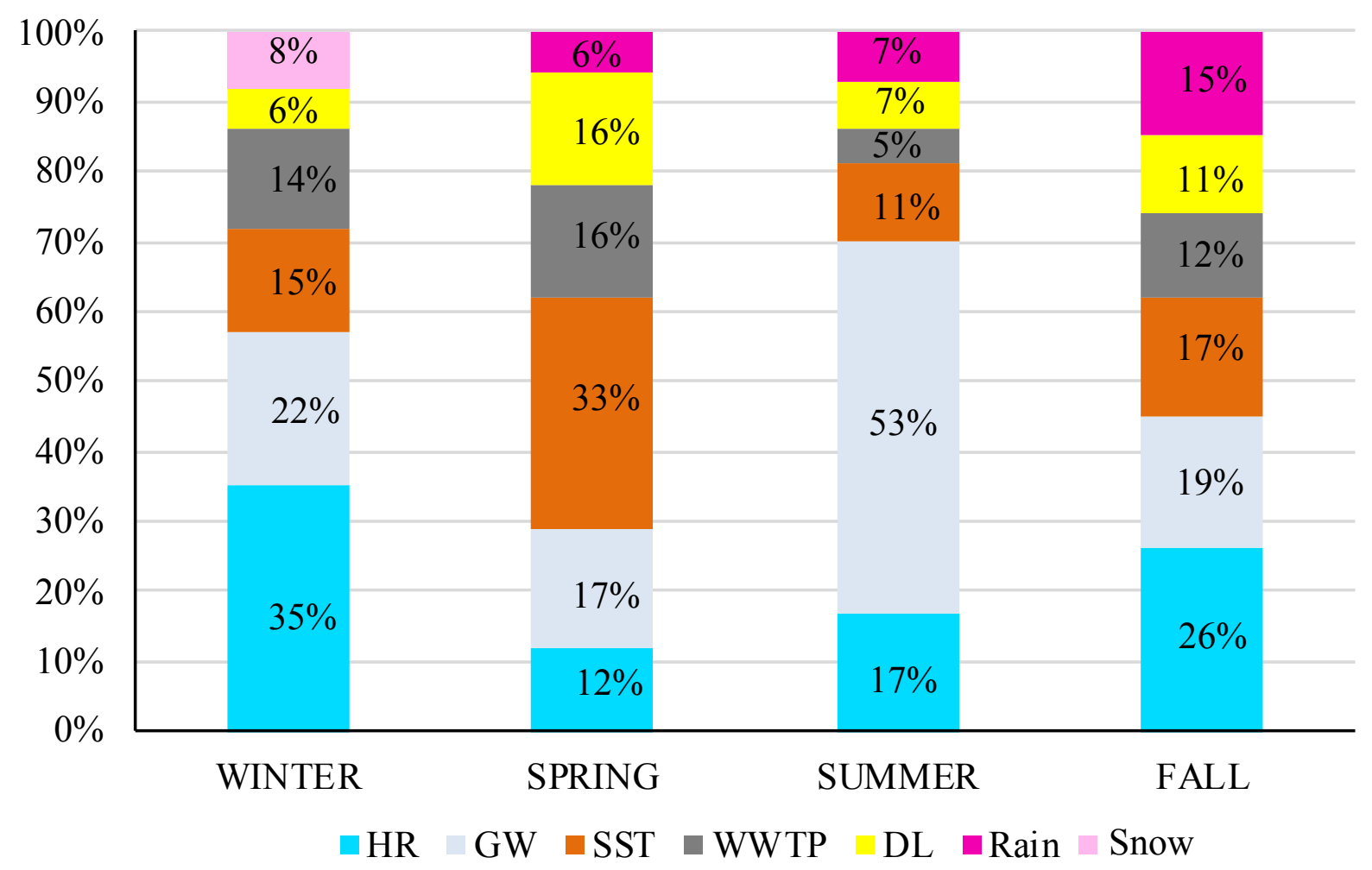

Figure 5. The mean seasonal contribution predicted in IsoSource for each water source of water: HR (Hurons River), GW (groundwater), SSTs (small stream tributaries), WWTP (wastewater treatment plants), DL (Delage Lake), rain and snow. 

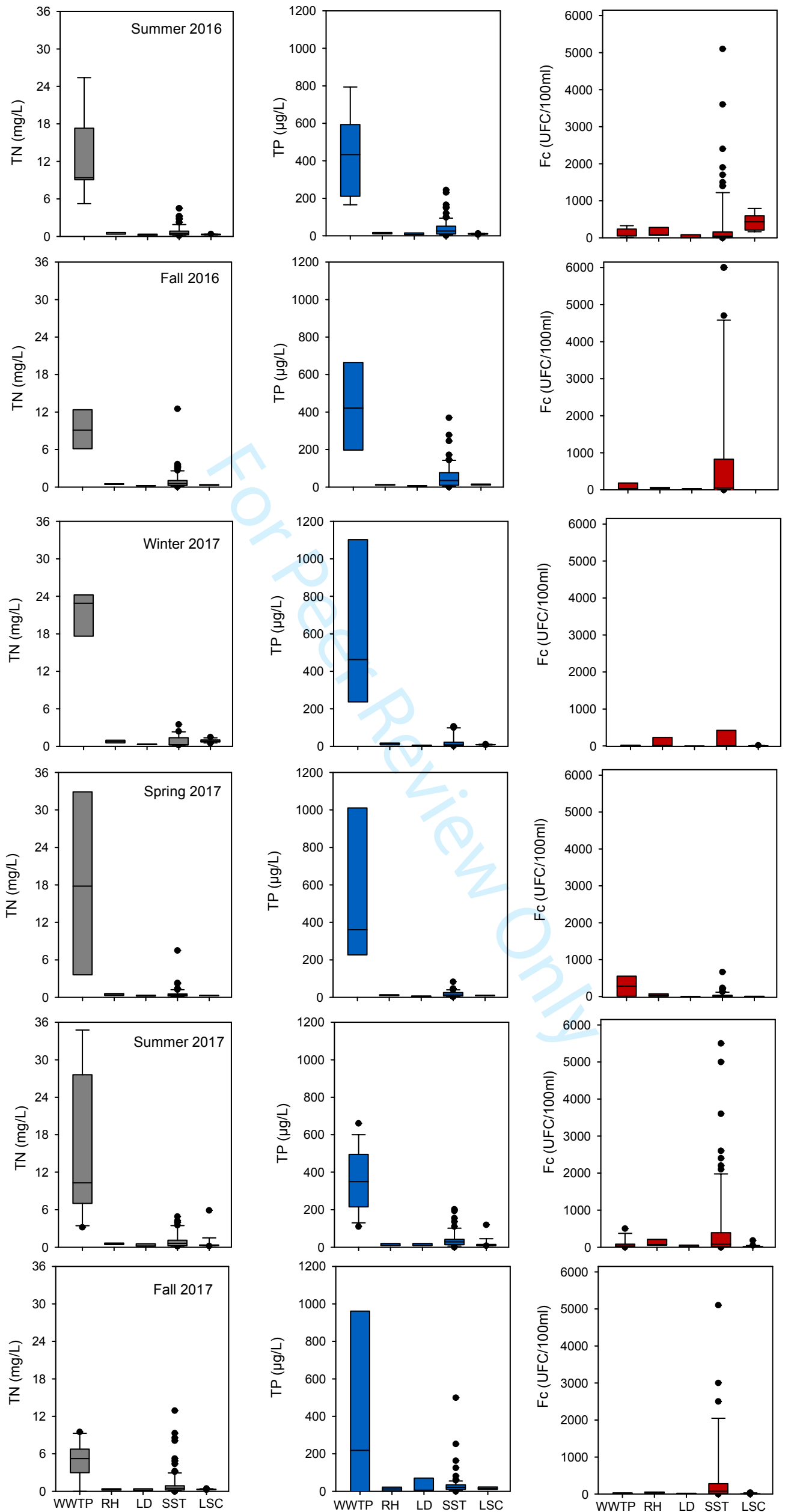

URL: https://mc.manuscriptcentral.com/tcwr 
Figure 6. Seasonal concentrations of total nitrogen (TN dark grey), total phosphorous (TP blue) and fecal coliforms (Fc red) from four sources of water (WWTP = wastewater treatment plants, $\mathrm{HR}=$ Hurons River, DL $=$ Delage Lake, SSTs $=$ small stream tributaries $)$ and Lake St. Charles (LSC). Mean concentration values from both WWTP effluents are presented (WWTP-ST = Stoneham-and-Tewkesbury, WWTP-LD = City of Lac Delage). The nutrient and Fc concentrations of ground water and precipitation were not measured, and the Fc concentrations of LSC were not measured in 2016. 

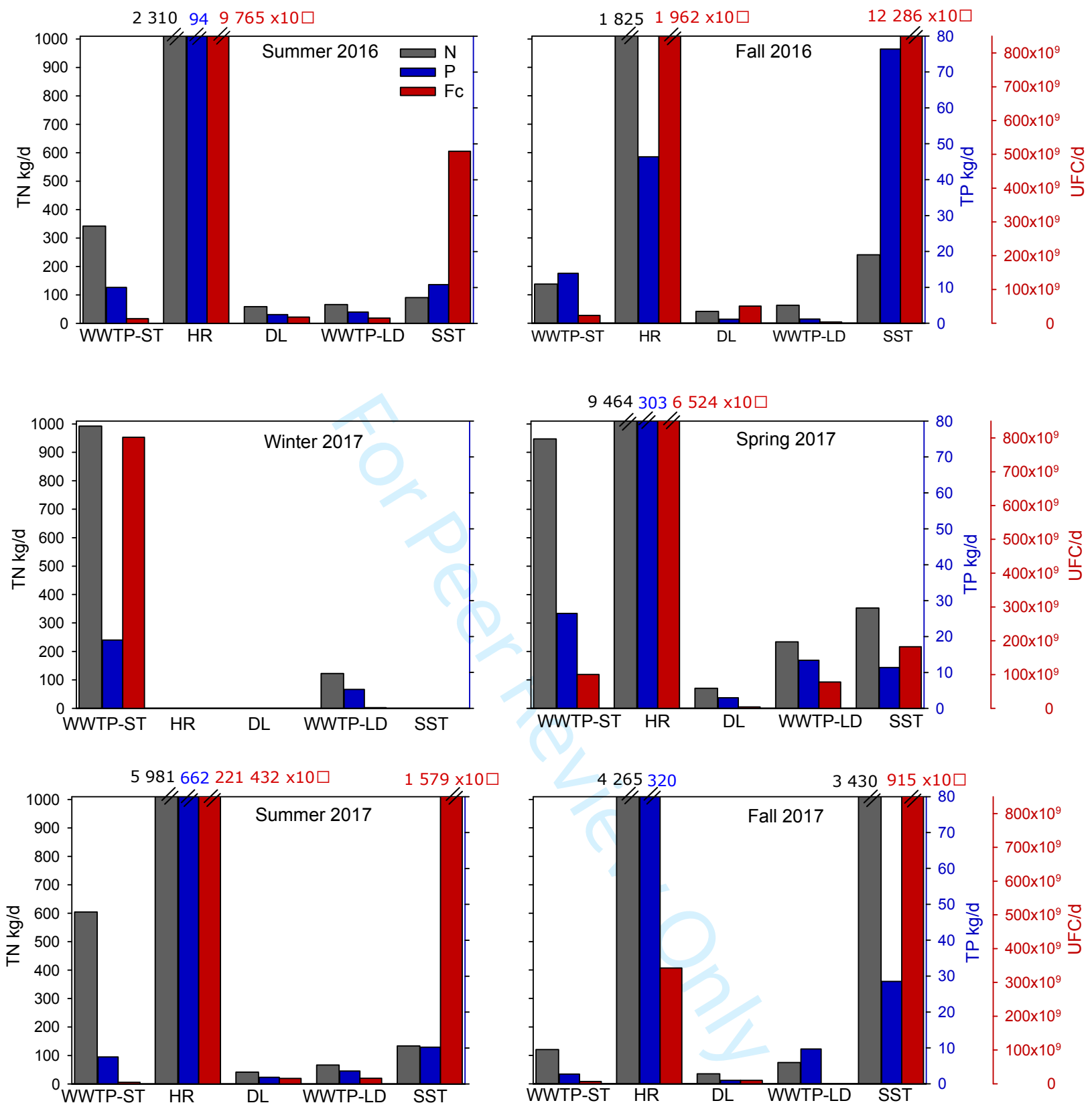

Figure 7. Seasonal mass fluxes of total nitrogen (TN dark grey), total phosphorous (TP blue) and fecal coliforms (Fc red) in wastewater treatment plant effluent of Stoneham-and-Tewkesbury (WWTP-ST), Hurons River (HR), wastewater treatment plant effluent for City of Lac Delage (WWTP-LD), Delage Lake (DL) and small stream tributaries (SSTs). Mass fluxes for HR, DL and SSTs were not calculated for Winter 2017, because discharges were not measured. HR mass fluxes include WWTP-ST mass fluxes as the latter is located upstream of the HR sampling station (Figure 1). 